\title{
The Direction of Generic Skills Courses at National University of Malaysia (UKM) towards Fulfilling Malaysian Qualifications Framework
}

\author{
Nazri Muslim ${ }^{1} \&$ Nasruddin Yunos ${ }^{1}$ \\ ${ }^{1}$ Centre for General studies, National University of Malaysia, Malaysia \\ Correspondence: Nazri Muslim, Centre for General studies, National University of Malaysia, Malaysia. E-mail: \\ nazrimuslim@yahoo.com
}

Received: November 29, 2013

Accepted: December 26, 2013 Online Published: January 26, 2014

doi:10.5539/ass.v10n4p195

URL: http://dx.doi.org/10.5539/ass.v10n4p195

\begin{abstract}
One of the key issues of the country is poor command of certain skills among university graduates from Public Higher Education Institute (PHEI). This matter has increased the rate of unemployment among graduates. This is because the industry as one of the key sectors of the economy generators needs human capital that masters various skills. The industry is facing global competition that requires them to participate and compete. Hence, to ensure that their position remains strong and relevant, human capital that masters skills such as communication skills, decision making, teamwork and others are urgently needed. Hence the emphasis on the aspects of these skills should be incorporated in the national education system. This article discusses the direction of generic skills courses at the National University of Malaysia in fulfilling the needs of Malaysian qualifications framework. This study is performed through analysis methodology on relevant documents in the matter. The study found that the National University of Malaysia has already implemented adoption of generic skills in courses offered, in fulfilling Malaysian qualifications framework. This will produce a student that is equipped with generic skills and further meets the needs of the job market.
\end{abstract}

Keywords: generic skills, Malaysian qualification framework, National University of Malaysia, general studies

\section{Introduction}

Mastery in certain skills is very important for the country to achieve progress. Mastery of these skills is regarded as one of the main conditions that need to be addressed by the country. This is because through the skills, development process will be smoother and continuous. In addition, mastery of these skills will generate further income for the country thus strengthening its economic position. Therefore, recognizing the importance of the mastery of these skills, the government has been proactive in planning and formulating various policies. One of the key concepts in the implementation of higher education policy is the implementation of the Generic Skills in Public Higher Education Institute (PHEI) in the country. It is hoped that the implementation of these skills will be able to produce highly skilled human capital which could help towards the development of the country to make Malaysia an industrialized country towards the year 2020. This article discusses the direction of Generic Skills courses at National University of Malaysia in fulfilling the needs of Malaysian qualifications framework.

\section{Generic Skills and Marketability}

Malaysian Qualifications Framework (MQF) was established as one of the government efforts to improve the level of higher education in this country. This framework is to ensure the quality of academics offered is equal academic programmes offered by universities abroad. For this purpose, a strategic partnership between PHEI in Malaysia and world's leading universities is established. To improve academic quality in this framework, the ministry also strives to increase the number of academic staff with doctorate qualification in all PHEI to at least 75 percent by 2015 (Bernama, 2006).

In issues related to failure of obtaining job opportunities among graduates and their relevance to soft skills, according to Mustapa Mohamed (Bernama, 2007) it was associated with poor command of English, weak in leadership aspect, sense of belonging and lack of communication skills.

According to Muhyiddin Yassin (Bernama, 2007) the students of higher education institutions (HEI) need to 
equip themselves with generic skills, such as problem-solving skills or produce something through creative spark of ideas and innovation. Students also need to take a more creative approach in exploring knowledge through a variety of sources and not just from the classroom alone. He also stressed the importance of mastery in leadership and efficient organization management skills which can be obtained and enhanced through participation in associations or clubs in HEI.

Demand for Generic Skills (GS) is very high especially in the workplace. Employers always want to ensure the success of their business by recruiting and retaining employees who have a broad range of various skills rather than personal characteristics as well as technical skills.

Esa, Abd. Hadi and Mohd Salleh (2007) conducted a study to determine whether the co-curricular activities conducted in polytechnics in Malaysia applied generic skills to prepare students to be prospective employees who could potentially meet the needs of the industry in Malaysia. The study found that polytechnic graduates obtained a good command in generic skills after learning it through co-curriculum which meets the requirements of industries in Malaysia.

\section{Previous Studies}

Hanum Hassan et al. (2008) in a study of the Bakti Siswa Perdana program on 270 UniMAP students showed that the students have a good perception towards the program, agreeing that it was able to improve their soft skills. The findings of her studies also showed that the communication element is seen as the highest key element obtained by the students compared to other elements presented. Her findings also showed that there were no differences in students from different gender over soft skills they acquired throughout the Bakti Siswa Perdana program.

Noreen, Mohd Nihra, Mohamad Said and Mohd Fadzli (2007) reported in their study entitled The Level of Generic Skills Readiness among final year students who took Physics subject in Education Faculty in UTM Skudai based on the seven generic skills outlined in the UTM Graduate Attributes found that majority of the respondents were at a high level of readiness based on seven generic skills assessed. The study also found that students strongly agreed on the improvement in the standard of English in teaching and learning process.

Haslinda, Muhammad Nubli and Zarina (2005) and Noreen, Mohd Nihra, Mohamad Said and Mohd Fadzli (2007) sees the role of co-curricular activities in developing individual's leadership skills. According to them, extra-curricular activities is more successfully to laid, nurture and provide initial training in the aspects of leadership, personality and social skills among the students. Esa, Abd. Hadi and Mohd Salleh (2007) had conducted a study to determine whether the co-curricular activities conducted in polytechnics in Malaysia applied the generic skills to prepare students to be prospective employees who could potentially meet the needs of the industry in Malaysia. The study found that polytechnic graduates acquired good generic skills after learning it through co-curriculum, thus meets the needs of the industry in Malaysia.

This finding is similar to what was reported by Haslinda, Muhammad Nubli and Zarina (2005) which highlighted that integrated programs implemented by the university were capable of producing engineering students who are skilled in various aspects. These findings proved that integrated programs such as Bakti Siswa Perdana program which emphasized student involvement were able to develop soft skills among the students. Therefore, these programs should be encouraged in the university because the result proved to be positive. Implementing this program should not be difficult because the University has all the facilities and amenities required for its implementation. One issue that may need to be importantly considered in this case is determining appropriate modules to be implemented which are capable of forming soft skills among the students who participated. Without the use of compatible or appropriate module, we fear such programs will only be seen as "self-indulgent program". However, what is clear is that the findings of this study is somehow similar to what was commonly imagined by many, that is, a program such as Bakti Siswa Perdana will increase the level of communication among participants who were involved with their adopted family and the surrounding community. As more participants involved, the aspect of communication became more open and widened. If this pattern is a norm, then the findings were in tandem with the findings of previous studies.

\section{Problem Statement}

Generic Skill (GS) encompass a variety of contexts including living and working whereas collectively, GS consists of six major elements namely basic skills, human-related skills, thinking skills, personal skills, business-related skills and community-related skills.

According to Chang Peng Kee, Fauziah Ahmad and Faridah Ibrahim (2011), the mass media has explained some weaknesses of local graduates particularly in terms of well-established skill level in which it affects their chances 
of getting a job. They are said to be lacking the ability to communicate effectively, less receptive to the learning process, and has low self-confident. Thus, having both cognitive concept of emotional intelligence and soft skills are a type of symbiosis or viewed as a much needed communal relationship once the students stepped out into the world of working. University-student relationship should be preserved so that throughout learning stages the students spent at the university, they are constantly reminded and exposed with various preparations for themselves to be an individual who are conversant and competent hence will be highly valued by the organization.

Specifically, the current globalized world of work demands a multi-skilled person. This includes the ability to adapt, teamwork ability, problem solving skills, creative, high-level of ability to face contingency situations, responsible and possess effective communication skills (NCVER, 2003). Furthermore, active relationship in wisely capitalizing niche skills is expanding globally, thus demanding the mastery of Generic Skills (NCVER, 2003). Generic skills are among the elements that enable a student to be accepted in the globalized world of work, in a variety of occupational fields such as science, engineering, business, education, etc.

From another point of view, Generic Skills is not only required in terms of the education program alone but it is also needed in the organizational context to improve service excellence as well as enhancing the level of respect for a country as a reflection of the quality of services exhibited (The British Council, 2007). In the context of specific individual development, Generic Skills is currently seen as highly important because the level of competition is so fierce, especially in the world of global economy, the need for knowledge creation and up to date information, a wider scope of cross-bordering communication and the increase in the need for human capital capable of multitasking (Kumar, 2012).

\section{The Importance of Generic Skills}

All of the above statements indicated that the process of Generic Skills adoption is the responsibility of all parties. This responsibility is seen as highly important as an assurance of the integrity of the country through contribution of the country's highly-skilled human capital. Developed countries like the United Kingdom, Australia, Germany, France, Denmark, Canada, Singapore, New Zealand and the United States are in the forefront in the practice of Generic Skills (NCVER, 2003). Through the implementation of these Generic skills, the quality of the nation's human capital can be assured in contributing not only on the national level, but also on the international level. But in the effort to apply this Generic Skills, local mould which is rich in religious and cultural aspects should also be considered seriously. This is required to highlight Generic Skills which are rich in national identity as well as utilize skills acquired from the world abroad, as a wisely shared item.

\section{Concept of Generic Skills}

In an effort to define the soft skills (SS) elements to be implemented and accepted by HEI, research and expert opinion as well as the experience of HEI which already implemented it has to be taken into account. As a result, seven key elements listed below have been selected for implementation in HEI:

1) Communication Skills

2) Critical thinking and Problem Solving Skills

3) Teamwork Skills

4) Lifelong Learning and Information Management

5) Entrepreneurial Skills

6) Professional Ethics and Morality

7) Leadership Skills

Each element can be refined and detailed into two groups, namely the Must-have Soft Skills-MSS (must have) and Supplementary Soft Skills-SSS (good to have). While attention must be given to the effort to produce human capital with MSS, SSS adoption should also be encouraged. Every university should be given the flexibility to choose the SSS to be applied. All elements of the proposed SS must be mastered by every student and should be evaluated in a comprehensive and effective manner.

\subsection{Must-Have Soft Skills and Supplementary Soft Skills}

Soft skills listed are divided into two categories: Must-have Soft Skills (MSS) and Supplementary Soft Skills (SSS). 


\subsection{MSS-Must-Have Soft Skills}

"Must-have Soft Skills" is a skill that must be possessed by every HEI students. If these skills are not available, the student is deemed not competent in the relevant elements.

\subsection{SSS-Supplementary Soft Skills}

"Supplementary Soft Skills" is considered as generic skills that will add value to the student. If these skills are acquired by students together with MSS, hence the student can be assumed to have excellent competence in the relevant elements.

All of these soft skills (SS) must be integrated into the teaching and learning in HEI. These SS should not be further considered as hidden curriculum but should be implemented in a real and assessed according to the assessment and evaluation system effectively.

\subsection{Description of Soft Skill Elements}

\subsubsection{Communication Skills}

Communication skills involve effective communication in Malay and English in different contexts and with different communication participants. Descriptions of eight communication skill (CS) are as follows:

Table 1.

\begin{tabular}{lll}
\hline Level & Skills & Description \\
\hline CS1 & MSS & Ability to communicate ideas clearly, effectively and with confidence, orally and in writing. \\
CS2 & MSS & Ability to practice active listening skills and give feedback \\
CS3 & MSS & Ability to make a clear presentation with confidence and appropriate to audience \\
CS4 & MSS & Ability to use technology in the presentation \\
CS5 & SSS & Ability to negotiate and reach an agreement \\
CS6 & SSS & Ability to communicate with participants who have different communication cultures \\
CS7 & SSS & Ability to develop communication skills individually \\
CS8 & SSS & Ability to use nonverbal skills \\
\hline
\end{tabular}

\subsubsection{Critical Thinking and Problem Solving Skills}

Critical thinking skills and problem solving skills (CTPS) involves the ability to think critically, be creative, innovative, and analytical as well as the ability to apply knowledge and understanding to new and different problems. Description of seven CTPS skill levels are as follows: (Tinggi, 2006).

Table 2.

\begin{tabular}{|c|c|c|}
\hline Level & Skills & Description \\
\hline CTPS1 & MSS & Ability to identify and analyze problems in complex situations \\
\hline CTPS2 & MSS & Ability to develop and improve the skills of thinking \\
\hline CTPS3 & MSS & Ability to seek out ideas and find alternative solutions \\
\hline CTPS4 & SSS & The ability to think beyond the boundaries \\
\hline CTPS5 & SSS & Ability to make decisions based on evidence \\
\hline CTPS6 & SSS & Ability to survive and give attention to the responsibility given \\
\hline CTPS7 & SSS & $\begin{array}{l}\text { Ability to understand and adapt to the culture of the community and new working } \\
\text { environment }\end{array}$ \\
\hline
\end{tabular}

\subsubsection{Teamwork Skills}

Teamwork skills (TS) involves the ability to collaborate with others from different socio-cultural backgrounds to achieve a common goal. Description of five TS skill levels are as follows: 
Table 3.

\begin{tabular}{|c|c|c|}
\hline Level & Skills & Description \\
\hline TS1 & MSS & $\begin{array}{l}\text { Ability to build rapport, interact with others and work effectively with them to achieve the same } \\
\text { objective }\end{array}$ \\
\hline TS2 & MSS & Ability to understand and take alternate roles between team leaders and team members \\
\hline TS3 & MSS & Ability to recognize and respect the attitudes, behaviours and beliefs of others \\
\hline TS4 & MSS & Ability to contribute to planning and coordinating the efforts of the group \\
\hline TS5 & SSS & Responsible for the group's consensus \\
\hline
\end{tabular}

\subsubsection{Lifelong Learning and Information Management}

Lifelong learning (LL) involves independent study in the acquisition of new skills and knowledge. Description of three levels of LL is as follows:

Table 4.

\begin{tabular}{lll}
\hline Level & Skills & Description \\
\hline LL1 & MSS & Ability to find and manage relevant information from various sources \\
LL2 & MSS & Ability to accept new ideas and capability of performing autonomous learning \\
LL3 & SSS & Ability to develop inquisitive mind and has hunger for knowledge \\
\hline
\end{tabular}

\subsubsection{Entrepreneurial Skills}

Entrepreneurial skills (ES) involves the ability to explore opportunities and develop an awareness of the risks (risk awareness), creativity and innovation in business and employment-related activities. Description of four levels of ES are as follows:

Table 5 .

\begin{tabular}{lll}
\hline Level & Skills & Description \\
\hline KK1 & MSS & Ability to identify employment opportunities \\
KK2 & SSS & Ability to formulate a business plan \\
KK3 & SSS & Ability to develop, explore and seize business opportunities and jobs \\
KK4 & SSS & Ability to be self-employed \\
\hline
\end{tabular}

\subsubsection{Professional Ethics and Morality}

Professional ethics and morality (EM) involves the ability to adopt a high moral standard in professional practice and social interaction. The following is the description of the three levels of EM:

Table 6

\begin{tabular}{lll}
\hline Level & Skills & Description \\
\hline EM1 & MSS & $\begin{array}{l}\text { Ability to understand the impact of economic, environmental and socio-cultural in professional } \\
\text { practice. }\end{array}$ \\
EM2 & MSS & $\begin{array}{l}\text { Ability to analyze and make decisions in solving problems related to ethics } \\
\text { EM3 }\end{array}$ \\
SSS & Ability to practice ethical behaviour, in addition to having a sense of responsibility \\
\hline
\end{tabular}




\subsubsection{Leadership Skills}

Leadership skills (LS) involves the ability to practice leadership in a variety of activities. Description of LS levels are as follows:

Table 7.

\begin{tabular}{lll}
\hline Level & Skills & Description \\
\hline LS1 & MSS & Knowledge of the basic theory of leadership \\
LS2 & MSS & Ability to lead projects \\
LS3 & SSS & Ability to understand and take alternate roles between team leader and team member \\
LS4 & SSS & Ability to supervise team members \\
\hline
\end{tabular}

\section{Malaysian Qualification Framework}

Malaysian Qualification Framework (Kerangka Kelayakan Malaysia, KKM) is Malaysian declaration on local qualifications and qualities possessed by those qualifications. MQF is an instrument that develops and classifies qualifications based on a set of criteria agreed nationally and benchmarked with international practice and explains the level of learning, learning outcomes and credit system based on student academic load. These criteria are accepted and used for all qualifications awarded by higher education providers. Thus, MQF integrates and connects all national qualifications (Malaysian Qualification Framework, 2012).

MQF also provides educational pathways which correlates these qualifications systematically. This allows individuals to progress in higher education through credit transfer and recognition of prior experiential learning (pengiktirafan pengalaman-pembelajaran terkumpul) derived from formal learning, non-formal and informal regardless of time and place, in the context of lifelong learning (Malaysian Qualification Framework, 2012).

In the 9th Malaysia Plan, in the aspects of producing tertiary institutions, efforts will be made to improve the quality of tertiary education, to reach international standards. Hence, local institutions of higher education will be benchmarked against international standards and a rating system will be introduced. Higher Education Institutions are also required to comply with standard quality assurance procedures as stipulated in the Malaysian Qualifications Framework (MQF). To support the implementation of the MQF and to establish an integrated quality assurance system, the Malaysian Qualifications Agency will be established. The quality of academic personnel will be enhanced through implementation of more development programs for them. In addition, the number of academic staff with doctorate qualification in public universities will be increased further to reach the target of 60 per cent of the academic staff by 2010. To improve the quality and global view of the university and academic personnel, alliances with leading international institutions will be pursued including through collaborative research (9th Malaysia Plan, 2006).

\section{Direction of the National University of Malaysia}

National University of Malaysia is one of the research universities that ensure the achievement of Generic Skills in courses offered are successfully implemented as required in Malaysia Qualification Framework or MQF. Three categories of learning outcomes stated in the Malaysian Qualification Framework qualification level namely qualification level, field of study and programs of study are always assured to be performing well (Malaysian Qualification Framework, 2012). Faculty of Engineering, Universiti Kebangsaan Malaysia through courses offered clearly put an emphasis on Generic Skills aspects. Besides emphasizing the seven aspects of generic skills, the University further added three more generic skills namely the knowledge of the field, technical and environmental awareness (Universiti Kebangsaan Malaysia, 2007).

UKM is always aggressive and proactive in ensuring these generic skill courses are implemented according to Malaysia Qualification Framework. In the Faculty of Engineering, this aspect was also emphasized in the implementation concept of The Third Teaching and Learning Congress (Kongres Pengajaran dan Pembelajaran UKM, 2011). This congress is about sharing of experience, research and best practices among academic staff of UKM. This sharing involves teaching \& learning, measurement \& evaluation, supervision and professional development of academic staff (Kongres Pengajaran dan Pembelajaran UKM, 2011).

$\mathrm{MQF}$ was given the responsibility to assure the quality of higher education for both the public and private sectors. MQF stipulates each program take into account the element of project planning and management as one of the learning outcomes of the program. 


\section{Conclusion}

From the above discussion, it clearly shows the importance of generic skills to meet the Malaysian Qualifications Framework. There are seven key elements of Generic Skills which are emphasized by public institutions of higher education namely Communication Skills, Critical Thinking and Problem Solving Skills, Teamwork Skills, Learning and Information Management, Entrepreneurial Skills, Professional Ethics and Morality and Leadership Skills. In this case, the National University of Malaysia as a research university in the country, has placed emphasis on Generic Skills in the Malaysian Qualifications Framework through the aspects of teaching and learning. In this case, higher education has a fundamental role in producing knowledgeable and highly skilled individuals who are also able to contribute to the formation of advanced, harmonious and prosperous country. This is in line with the important aim of National Education Philosophy; individual must not only be knowledgeable and skilled, but at the same time should be strong and balance in terms of physical, emotional, spiritual and intellectual.

\section{Recommendation}

Soft skills should be emphasized in the producing human capitals that meet the needs of the country. Therefore, students who are studying in UKM should be equipped with the soft skills. As an encouragement, good evaluation and consideration should be given to the students who show improvement in their soft skills. UKM revised the curriculum periodically so that students are equipped with better soft skills in producing graduates who are able to meet the current job market needs.

\section{Acknowledgement}

This research was fully funded by the National University of Malaysia (UKM-PTS-2011-125).

\section{References}

9th Malaysia Plan. (2006). Rancangan Malaysia Kesembilan 2006-2010. Kuala Lumpur: Economic Planning Unit.

Bernama. (2006, March 21). Kerangka kelayakan Malaysia untuk tingkat taraf pengajian tinggi negara. Retrieved from http://www.bernama.com/bernama/v3/bm/news_lite.php?id=187008

Bernama. (2007, July 14). Ketiadaan Kemahiran Insaniah punca siswazah menganggur, kata Mustapa. Retrieved from http://www.blis.bernama.com/mainHome.do

British Council, Genric Skill Dictionary. (2007, March 7). Retrieved from http://www.britishcouncil.org/africa-britishcouncil-generic-skills-dictionary

Esa, A., Abd Hadi, M. Y., \& Salleh, D. B. M. (2007, December 12-14). Peranan ko-kurikulum di Politeknik dalam memenuhi keperluan pihak industri di Malaysia. Paper presented in Persidangan Pengajaran dan Pembelajaran di Peringkat Pengajian Tinggi 2007, Hotel Palace of the Golden Horses, Seri Kembangan, Selangor.

Esam, N. M., Said, M. N. H. M., \& Ali, M. F. (2007, December 12). Tahap kesediaan kemahiran generik pelajar tahun akhir yang mengambil mata pelajaran fizik di Fakulti Pendidikan UTM, Skudai. Paper presented in Persidangan Pengajaran dan Pembelajaran di Peringkat Pengajian Tinggi 2007, 12-14 Disember 2007, Hotel Palace of the Golden Horses, Seri Kembangan, Selangor.

Hashim, H. R., \& Ali, M. N. A. W. D. M. (2005, December 17). Pembangunan sahsiah mahasiswa bersepadu: Konsep dan pelaksanaannya di Kolej Universiti Kejuruteraan. Paper in di Seminar Kebangsaan Kursus Sokongan Kejuruteraan, 17-18 December 2005. Hotel Aseania, Langkawi.

Hassan, H., Ahmad, R., \& Bahari, A. (2008, December 5). Kemahiran Insaniah dan kepentingan penerapannya dalam program baktisiswa perdana UniMAP. Retrieved from http://www.dspace.unimap.edu.my

Kee, C. P., Ahmad, F., \& Ibrahim, F. (2011). Hubungkait antara Kemahiran Insaniah prasiswazah dengan dimensi hubungan organisasi-publik. Jurnal Personalia Pelajar, 14, 23-26.

Kumar, S. (2012, March 23). Generic skills in personnel development. Jabatan Politeknik Kementerian Pengajian Tinggi. Retrieved from http://www.politeknik.gov.my

Malaysian Qualification Framework. (2012, March 25). Retrieved from http://www.mqa.gov.my/berita20100105.cfm

NCVER. (2003). Defining Generic Skills. Technical document of the National Centre for Vocational Education Research. Australia National Training Authority 2003. Retrieved from 
http://www.ncver.edu.au/popups/limit_download.php

Pengajaran, K., \& Pembelajaran UKM 2011. (2011, December 18-20). Retrieved from http://www.ukm.my/kongres/v2

Tinggi, K. P. (2006). Modul Pembangunan Kemahiran Insaniah (Soft Skills) Untuk Institusi Pengajian Tinggi Malaysia. Serdang, Selangor: Universiti Putra Malaysia.

Universiti Kebangsaan Malaysia. (2007). Kemahiran Insaniah Perlaksanaan dan Pengukuran. Retrieved from http://www.eng.ukm.my

\section{Copyrights}

Copyright for this article is retained by the author(s), with first publication rights granted to the journal.

This is an open-access article distributed under the terms and conditions of the Creative Commons Attribution license (http://creativecommons.org/licenses/by/3.0/). 